but more or less simultaneous whereas infections from other vectors are likely to be isolated.

Analyses of the prevailing air streams at the time of foot and mouth outbreaks earlier in 1967, in 1966 and 1965 are shown in the table. According to $\mathbf{M r}$ Hurst, none of them are likely to have been started by windborne virus, although in three cases winds were in the right direction for a short time before the outbreaks. However, the waves of scattered but simultaneous outbreaks of the disease on the Kent and Sussex coasts throughout the spring and summer of 1952 present a different picture. These outbreaks had all the characteristics of airborne origin; they occurred after favourable airstreams and at periods when bird migration was minimal. Traditionally, birds, especially starlings, have been suspected of spreading foot and mouth disease, but in fact their role, if any, is far from clear. The Gower report discussed the possibility of starlings spreading the disease in the 1951 infections, but in 1952 it is unlikely that they had anything to do with the dispersal of the disease. If anything, during the spring and early summer the starlings would be migrating from west to east. And during the latest epidemic starlings seem to have had little impact. The snow in early December 1967 caused them to migrate south-westerly from central England, the infected area, to the Gower coast, southwest England and even southern Ireland, but there were no corresponding outbreaks of the disease.

\section{Doing without the Dollar}

THe state of psychology in Canada is heavily dependent on support from the United States in the forms both of men and money. But United States funds are likely to decrease to half their present size by 1970 , and the Canadian Government must more than make good this gap if it is to finance the expected expansion of psychological activity in Canada.

Of the 1,600 psychologists working in Canada in 1966, 20 per cent were not Canadians and 11 per cent were Americans. Of the $\$ 3.5$ million granted in the same year for psychological research, roughly onethird each was contributed by Canadian, United States and other outside sources. According to a study by M. H. Appley and Jean Rickwood presented to the Science Council of Canada (Psychology in Canada, Science Secretariat, Ottawa), the costs of financing psychological research are likely to rise to $\$ 14.6$ million in $1970-71$ and to $\$ 30 \cdot 8$ million in $1975-76$. These estimates are based on the assumption that, compared with 1966, the number of research projects will increase by 100 per cent by 1970 and 160 per cent by 1976 . The estimates include a 20 per cent sophistication factor and an allowance of 25 per cent for cost escalation.

Where will these funds come from ? The grant support from the US, far from keeping pace with this expansion, is expected to diminish rapidly, leaving the Canadian Government to foot almost the entire bill by 1975. The drying up of United States funds is presumably attributable to the containment of the rate of growth of US research spending in recent months.

If the level of spending on psychological research is not maintained, Canada must expect to lose a fair proportion of her foreign labour force, particularly the reverse brain drain from the United States. The median income for psychologists is $\$ 9,235$ in Canada against $\$ 11,500$ in the United. States, and the respective research grants per psychologist are $\$ 835$ and $\$ 4,900$. The necessary expansion of Canadian universities has depended heavily on American personnel and will continue to do so; differentials between the two countries cannot therefore be allowed to increase. Canadian faculties must remain competitive with those in the US in order to retain American psychologists.

\section{Health in the United States}

The United States Health Education Committee has laboriously compiled a rather unusual document (1966, $\$ 5 \cdot 25$ ) which outlines the major killing and crippling diseases in the United States, and describes what is being done to reduce their incidence. Five of the fifteen main causes of death are listed.

$\begin{array}{lcc}\begin{array}{c}\text { Main causes } \\ \text { of death }\end{array} & \begin{array}{c}\text { Estimated deaths } \\ \text { in } 1965\end{array} & \begin{array}{c}\text { Percentage } \\ \text { total deaths }\end{array} \\ \text { Cardiovascular-renal } & 999,850 & 55 \\ \quad \text { diseases } & 296,320 & 16 \\ \text { Cancer } & 106,900 & 6 \\ \text { Accidents } & 61,460 & 3 \\ \text { Pneumonia } & 55,060 & 3\end{array}$

\section{early infancy}

From the report it seems that deaths attributable to rheumatic fever, tuberculosis, appendicitis, influenza, whooping cough, acute nephritis, dysentery and anaemias have all decreased within the past decade or two and, furthermore, during the 22 years between 1943 and 1965, the life expectancy for Americans increased by 7 years. At the time the information was compiled, the discovery of a reliable contraceptive pill was acclaimed as the most important medical advance in the sixties, but listed among other major research pay-offs and developments in other fields of medical research are anticoagulant drugs for treating heart attack, antihypertension drugs for hypertensive heart disease, methotrexate and actinomycin $D$-chemotherapeutic agents for certain types of cancer and, of course, a number of vaccines. New tests have been devised for detecting gonococeal arthritis and phenylketonuria, and many new anticonvulsant drugs have been developed.

The cost of illness to the United States in terms of lost working days and private expenditures for health and medical services is staggering - $\$ 30$ billion. The approximate financial aid given to medical research in the United States is as shown.

Cost of illness to the United States

$\$ 30 \quad$ billion

Amount repaid in income and excise taxes by individuals whose lives have been saved by medical research

Total spent on medical research by the National Institutes of Health

Amount spent by other departments of the Federal Government on medical and "health related" research including the pharmaceutical industry

What the chief national voluntary health agencies raise
$\$ 1 \cdot 2$ billion

$\$ 1 \cdot 2$ billion

$\$ 0.75$ billion

$\$ 0 \cdot 036$ billion
The growth of population receives considerable attention in the document, and it is estimated that, at the present rate of growth, the population of the United States will double before the end of the century. The effect of this, it is suggested, will be to burden rather 